\title{
Disability Status, Housing Tenure, and Residential Attainment in Metropolitan America
}

\author{
Samantha Friedman ${ }^{1, \dagger}{ }^{+}$Kaya Hamer-Small ${ }^{2, *, \dagger}$ and Wendie Choudary ${ }^{3}$ \\ 1 Department of Sociology, University at Albany, SUNY, Albany, NY 12222, USA; samfriedman@albany.edu \\ 2 Social and Behavioral Sciences and Human Services, Broward College, Davie, FL 33314, USA \\ 3 Kinder Institute for Urban Research, Rice University, Houston, TX 77030, USA; wendie.n.choudary@rice.edu \\ * Correspondence: khamersm@broward.edu; Tel.: +001-954-201-6592 \\ + The authors contributed equally to the article.
}

Received: 30 June 2018; Accepted: 23 August 2018; Published: 29 August 2018

check for updates

\begin{abstract}
In 2010, 18.7 percent of the U.S. non-institutionalized population had a disability. Despite the existence of the Fair Housing Amendments Act (FHAA), which prohibits housing discrimination on the basis of disability, recent research has found that individuals and/or families with disabilities live in poorer quality housing and neighborhoods than those without disabilities. However, no research has examined such disparities in residential attainment separately by housing tenure; our research seeks to fill this gap. The findings suggest that residential disadvantage among households with people with disabilities is worse in the sales market compared to the rental market. These findings are discussed as they relate to theories on residential attainment. The implications of our study suggest that more attention should be given to people with disabilities as they navigate the housing market, particularly in the sales market, and that greater enforcement of the FHAA is warranted in the sales market.
\end{abstract}

Keywords: disability-status; residential attainment; housing tenure

\section{Introduction}

In 2010, approximately 56.7 million people (18.7 percent) of the U.S. civilian, non-institutionalized population had a disability, among whom about 38.3 million people (12.6 percent) had a severe disability (Brault 2012). In 1988, the Fair Housing Amendments Act (FHAA) was passed to amend Title VIII of the Civil Rights Act of 1968, which prohibits discrimination on the basis of race, color, religion, sex, or national origin in housing sales, rentals, or financing. The FHAA extends this protection to persons with a disability and families with children. The FHAA was designed to help persons with disabilities reach the goal of independent living and to be incorporated into the American mainstream, thus ending unnecessary exclusion (Stanton 2002, p. 22; Smith et al. 2008). Projections show that by the year 2050, households with at least one member who has a long lasting physical disability will constitute 27.1 percent of the non-institutionalized population (Smith et al. 2008).

Discrimination against people with disabilities represents a large share of housing discrimination complaints (Abedin et al. 2018). In 2017, of all the complaints made to the Department of Housing and Urban Development (HUD) alleging housing discrimination, 61.9 percent were based on disability status, while 23.5 percent were on the basis of race, and 10.1 percent on national origin (Abedin et al. 2018). The National Fair Housing Alliance (NFHA) maintains that part of the reason for such high levels of complaints on the basis of disability is because it is easier to detect. HUD has an office devoted to housing issues for people with disabilities, making it easier for people to get information on how to file complaints. 
The large number of complaints on the basis of disability raises the question of whether the presence of people with disabilities in households adversely affects their residential attainment relative to households without people with disabilities. There is a small but growing literature that addresses this issue. Hoffman and Livermore (2012) and Newman (2003) find that individuals and/or families with disabilities live in housing of poorer quality (i.e., smaller, older, greater maintenance deficiencies) compared to households without people with disabilities. Moreover, White et al. (1994) found that households with people with disabilities are more likely to carry severe housing cost burdens than households without people with disabilities. In addition, households with at least one disabled person tend to rate their neighborhoods lower, report fewer neighborhood benefits, and more frequent neighborhood problems compared to households without people with disabilities (Newman 2003; Smith et al. 2008; Hoffman and Livermore 2012).

However, no research has examined disability status disparities in residential attainment separately by housing tenure. According to NFHA $(2013,2014)$, enforcement of the Fair Housing Act is lower in the sales market relative to the rental market. Testing and detecting discrimination against people with disabilities is easier in the rental market, because denial of reasonable accommodation is apparent, and buildings covered by the FHA that are inaccessible are obvious to detect (NFHA 2014). Additionally, in the rental market, "interactions are quick and rental rates are usually advertised," making the detection of discrimination more straightforward (NFHA 2013, p. 20).

This raises the question of whether the poorer housing and neighborhood quality found in previous research is more prevalent in the sales market, where enforcement is more difficult, compared to the rental market. The residential disparities between individuals with or without a disability may be further exacerbated when considering homeownership, due to it being an indicator of wealth (Conley 1999; Oliver and Shapiro 1995; Hoffman and Livermore 2012). Therefore, it is important to fill this gap in the literature by examining the role of housing tenure in residential disparities by disability status. Using data from the 2009 national panel of the American Housing Survey (AHS), our paper seeks to address the limitations of previous research and answer three main questions: (1) Does the disability status of householders matter in shaping their neighborhood and housing quality for renters and owners? (2) Controlling for relevant socioeconomic and demographic characteristics, to what extent does disability status shape the residential attainment of owners and renters? and (3) With respect to the latter, is the impact of disability status similar or different by household housing tenure? This research is the first of its kind to address these questions. The 2009 national AHS data are the best suited to this analysis because, in the 2011 panel, the AHS removed the neighborhood characteristics, and in the 2013 panel, they only asked the neighborhood questions for half of the sample (AHS 2012).

\section{Theory and Background}

To our knowledge, no theoretical discussion exists regarding how disability status shapes residential attainment, despite the fact that the population with one or more disabilities is a growing minority population in American society. To explain the variation in housing and neighborhood quality by housing tenure and disability status, we begin with the spatial assimilation model (Alba and Logan 1991, 1993; Massey 1985; Alba and Nee 2003; Logan and Alba 1993; Lee et al. 2008; Iceland and Scopilliti 2008), and also use a discrimination model. According to the spatial assimilation model, socioeconomic status determines the residential distribution of households across neighborhoods. The theory of spatial assimilation argues that the socioeconomic advancement for minority populations leads to residential integration within mainstream society (Massey 1985). Several factors associated with social and economic well-being, such as health, quality of education, access to employment, crime exposure, and social prestige, are determined by residential location (Ellen et al. 2001; Baum et al. 2016). Thus, as SES increases, these minority populations attempt to transfer their socioeconomic advancements into a higher spatial position, implying assimilation with majority members. 
For this research, the spatial assimilation model will be used to explain variation in housing and neighborhood outcomes of households with people with disabilities and households without people with disabilities (i.e., the majority group) among owners and renters. In this case, the model maintains that the gap in residential attainment between households with and without people with disabilities is attributable to the differences that exist in their levels of socioeconomic attainment, whether they are owners or renters.

While the spatial assimilation model characterizes variation in household residential attainment mostly as a function of differences in their socioeconomic status, the role of demographics, particularly aging, also need to be considered when focusing on variation between households with and without people with disabilities. Older households are generally more likely to be owners, and are also more likely to experience disabilities (Smith et al. 2008). In 2014, 60.5 percent of adults aged 65 and older reported having at least one basic actions difficulty or complex activity limitation (Health, United States, 2015). Based on the American Housing Survey National Tables (2009), of the 23.1 million households headed by older persons in 2009, 80 percent were owners and 20 percent were renters (AoA 2011, p. 12). Thus, part of the residential inequality that exists between owner households with and without people with disabilities may be attributable to the fact that older people with disabilities are more likely to live in older constructed housing units that need more home maintenance and repairs, and they live in physically distressed neighborhoods that they are less likely to relocate from (Golant 2008; Newman 2003).

Using a discrimination model, we can analyze the role of discrimination in determining the residential attainment of households by disability status and housing tenure. We know from Hemingway $(2010,2011)$ that people with disabilities are especially likely to face housing discrimination and barriers to securing affordable, accessible housing. Based on the discrimination model, structural and inter-personal discrimination experienced by households with people with disabilities contributes to an unequal pattern of access to advantaged areas and housing. The large number of complaints alleging housing discrimination that were identified at the outset of the paper and the lack of effort on the part of providers to accommodate households with people with a disability highlights that households with people with disabilities are more affected by discrimination than households without people with disabilities.

Similar to the place stratification model used to explain racial and ethnic inequality in residential attainment (Logan and Molotch 1987; Massey and Denton 1993), the discrimination model offers an alternative view to the spatial assimilation model in characterizing the variation in residential quality between households with and without people with disabilities, focusing more on structural factors and less on variation in individual factors. The model maintains that despite having the income to purchase or rent a home, households with people with disabilities face discrimination based on their disability status that constrains their housing options, relative to households without people with disabilities. Thus, the tenets of the model suggest that household income is not the sole determinant of residential attainment. Findings from previous research confirm that disability status remains statistically significant after controlling for income and other measures of socioeconomic status, suggesting that these factors do not account entirely for the residential disadvantages faced by households with people with disabilities (Hoffman and Livermore 2012). There are likely to be structural barriers in place.

There are reasons to believe that the disability status residential disadvantage differs between renters and owners. Among renters, regulations among the housing laws, including those under the FHAA, all stipulate that existing facilities must enhance access and require that landlords allow tenants to make "reasonable accommodations" to their housing units to make them usable (Froehlich-Grobe et al. 2008). There is a lack of enforcement and non-compliance of the FHAA; studies have found that the vast majority of multi-family complexes (rental properties) do not comply with the FHAA's accessibility requirements, and that there exists an overall unmet need for housing modifications (Turner et al. 2005; Levy et al. 2015; Newman 2003; Chan and Ellen 2016). 
Discrimination in the design and construction process can contradict the intended benefits for households with people with disabilities. For example, in 2012, the U.S. Department of Justice (DOJ) settled a case with JPI Construction L.P. and other JPI entities where they alleged that JPI discriminated against people with disabilities in the design and construction of 210 multi-family units (NFHA 2013). This particular case received a lot of attention because JPI was required to pay $\$ 10$ million into a fund that will retrofit these properties to make them compliant with the FHAA. This is the largest fund ever created by the DOJ. However, this is not the first time that a settlement has been made based upon these allegations.

Homeowners with disabilities are expected to have achieved upward social mobility by achieving homeownership status, but this does not automatically mean their housing conditions will be better. Homeowners with disabilities bear the costs of modifications themselves (Froehlich-Grobe et al. 2008). They are less likely to spend money on routine maintenance, and their homes are less likely to contain dwelling modifications (Golant 2008, p. 5). Renters, on the other hand, have a better chance of moving into a modified multi-family unit or having a discrimination claim investigated and enforced (Pynoos and Nishita 2003).

Additionally, owners with a disability can face discrimination in financing that may contribute to their poorer residential quality, relative to owners without a disability. Such discrimination is not a problem in the rental market. According to NFHA (2013, p. 32), in 2012, the "DOJ settled a case with Bank of America in which it alleged the lender engaged in patterns or practices that violated the Fair Housing Act by discriminating against people on the basis of disability, and the Equal Credit Opportunity Act (ECOA) by treating public assistance recipients differently in the underwriting process." In this case, three separate home seekers who were trying to obtain housing were asked to provide documentation of any Social Security Disability Insurance (SSDI) they had received, in violation of the FHA and ECOA. This is one of the first major cases enforcing these laws in the owner market. It is likely that this type of discrimination is widespread, but it is harder to enforce, relative to the discrimination that occurs in the rental market. Among homeowners, the potential inaccessibility to credit would no doubt contribute to the residential disadvantages faced by households with people with disabilities compared to households without people with disabilities.

\section{Hypotheses}

The preceding theoretical discussion suggests a number of hypotheses in characterizing the impact of disability status on residential disadvantages experienced by renters and owners. Under the spatial assimilation model, it is expected that households with people with disabilities will be disadvantaged in their housing and neighborhood conditions. However, after controlling for socioeconomic status, demographic factors, such as age, and other relevant variables, it is expected that the residential disadvantages experienced by households with people with disabilities will decrease in magnitude or diminish. There is a possibility, however, that such characteristics may not fully attenuate the disability status residential disparities present among owners. Simply controlling for age and income differences between owners with and without disabilities may not be enough to capture the fact that older owners may have a harder time maintaining their homes, and therefore, are living in poorer quality homes and neighborhoods than homeowners without disabilities. Research has shown that older people with higher incomes are less likely to move from distressed neighborhoods, and when they do exit, they move to similarly distressed neighborhoods (Burkhauser et al. 1995; Golant 2008). Older owners are also less likely to spend money on routine maintenance and more likely to live in housing built during or prior to 1970, which will demand more upkeep over time (AoA 2011; Golant 2008). If such factors are not accounted for, the disability status disadvantage that persists may be a function of these factors.

The discrimination model maintains that the residential disadvantages faced by households with people with disabilities are attributable to the housing discrimination that they face, which constrain their residential options and relegate them to poorer quality housing and neighborhoods. Thus, such 
disparities will remain even after controlling for differences between households with and without people with disabilities in socioeconomic status, demographic factors, and other relevant characteristics. The preceding review of the literature suggests that renters may face slightly less disparities because enforcement of fair housing laws is greater in the rental market than in the sales market, although there is growing interest in the latter.

\section{Data and Methods}

\subsection{Data}

The 2009 AHS data are well suited for our bivariate and multivariate analyses of the housing and neighborhood outcomes of households with and without people with disabilities by housing tenure. These data come from a longitudinal, representative sample of approximately 620,000 housing units located throughout the United States that are surveyed bi- annually. The sample is spread over 394 primary sampling units that represent 878 U.S. counties and independent cities in all 50 states and the District of Columbia (U.S. Census Bureau 2011). Since 1985, the Census Bureau has interviewed the current sample of housing units, and in the 2009 panel, there was an unweighted response rate of $89 \%$ (U.S. Census Bureau 2011). The sample was picked randomly via systematic sampling so that every unit had a 0.05 percent chance of being in the sample (U.S. Census Bureau 2011). Between April and September of 2009, census enumerators collected the data by telephone or via in-person visits using a laptop survey instrument (U.S. Census Bureau 2011). Enumerators interviewed one person in each household that was at least 16 years of age, usually lived in the residence, and was knowledgeable about the characteristics of the house (U.S. Census Bureau 2011). Sampling weights (scaled down to maintain unweighted cell sizes) are used in all bivariate and multivariate analyses to correct for sampling design effects and potential undercoverage.

In 2009, the AHS included questions to determine the disability status of household members, which had not been present on the AHS since supplemental questions were present in the 1978 and 1995 panels (U.S. Census Bureau 2011). Because the AHS contains many questions on housing and neighborhood quality and housing tenure, the addition of the disability questions make the data ideal for our study. Indeed, no other dataset, to our knowledge, facilitates the ability to study this topic. While the 2009 data are a bit dated, they are the only panel of the AHS that asks all of the households in the AHS sample about the householder's disability status and about the quality of their neighborhoods.

Table A1 shows the characteristics of renters and owners combined in our analytical sample. It should be noted that the 2009 AHS has been compared to the 2009 American Community Survey (ACS), and has been found to underestimate the percent of households with persons with disabilities, which is thought to be due to (1) the fact that the ACS is a mail back questionnaire that affords more privacy to people answering it as compared to the AHS, which is a done by telephone or via an in-person visit; and (2) that the ACS asks about the characteristics about all of the people in the household via a roster, while the AHS only asks about other persons if the respondent answers affirmatively that there is someone in the household with a disability (Eggers and Moumen 2011). The data for the racial and ethnic composition and housing tenure match very closely to the data from the demographic and housing profiles available for the 2010 ACS via American Factfinder.

\subsection{Methods}

To measure our central dependent variables, we examine a given household's neighborhood conditions, residence in suburbs, and housing adequacy. Specifically, we use responses to questions asking about the presence of the following conditions within a half block of the building: abandoned buildings; buildings with bars on the windows; trash, litter, or junk in the streets, roads, empty lots or on any properties; and lack of nearby open spaces, such as parks, woods, farms, or ranches. We also use data from a question asking householders if crime was present in the neighborhood. However, 
the question does not restrict householders to considering crime within a half block of the building. We analyze whether the household lives in the suburbs, and a measure of housing adequacy gauging whether the unit is moderately or severely inadequate, relative to being adequate.

Our key independent variables gauge the disability status of the household. We use two main independent variables. One is a summary variable, which measures whether households contain at least one person who has at least one of the six types of disabilities included in the AHS: (1) hearing; (2) vision; (3) mental; (4) physical (walking or climbing stairs), which we denote as ambulatory; (5) self-care; and (6) go outside-home. The second main independent variable, used in a separate set of analyses, just focuses on whether households have at least one person with a physical or ambulatory disability (i.e., trouble walking or climbing stairs). We focus specifically on this latter variable because the subject of many housing discrimination complaints is the housing provider's inability to modify housing to accommodate people's physical limitations.

Similar to previous research (e.g., Alba and Logan 1991, 1993; Friedman and Rosenbaum 2007; Logan and Alba 1993; Rosenbaum and Friedman 2001), we include a number of control variables in our multivariate analyses that measure demographic characteristics of households, their socioeconomic status, and characteristics about their unit that might explain why disability status shapes the residential attainment of renters and owners. The demographic indicators include householder's age and three dummy variables-whether a female heads the household, a married couple heads the household, and children under 18 are present. We also include an indicator of the householder's nativity status. Socioeconomic status is gauged by several variables. Education is represented by two dummy variables indicating whether the households has (1) more than a high school degree; and (2) a high school degree (with less than a high school degree forming the reference group). We control for household median income and include three other income-related dummy variables indicating whether: (1) the household receives public assistance; (2) they receive supplemental income for their disability (either through SSI or workman's compensation); and (3) they receive housing assistance. Finally, we control for the households' duration in their housing units (i.e., in years), whether the housing unit is in the suburbs (except where suburban location is a dependent variable), and the region within which the household lives.

We use two analytical datasets for this study: one for renter households and one for owner households. We drop cases with missing values on any of the aforementioned independent or dependent variables. For renters, we drop $10 \%$ of cases due to missing values; for owners we drop $6 \%$ of cases. To address our research questions, we first conduct bivariate analyses of the 2009 AHS data to identify disparities between households with and without people with disabilities in neighborhood and housing outcomes by housing tenure. As mentioned above, we define disability in two ways: (1) using the overall summary indicator of disability, and (2) using ambulatory disability status. Thus, two sets of bivariate analyses are conducted. We then compare disability status differences in demographic, socioeconomic, and unit-related characteristics for renters and owners using these two disability definitions using the proc ttest command to compute t-tests in SAS. Finally, SAS multivariate analyses are conducted to identify how disability status affects household neighborhood and housing conditions, separately among renters and owners, controlling for demographic, socioeconomic, and unit-related characteristics. We conduct two sets of analyses, with one set using an overall indicator of disability status and the other using the indicator derived on the basis of persons with ambulatory disabilities being present in the household. We use logistic regression analyses (i.e., proc logistic) to examine the association between each of these two disability indicators and our neighborhood outcomes of interest. We cannot formally test the difference in the coefficients for our disability indicators between the model for renters and for owners because these coefficients are confounded with unobserved heterogeneity (Allison 1999). According to Allison (1999, p. 187), "differences in the degree of residual variation across groups can produce differences in coefficients that are not indicative of true differences." 


\section{Results}

Among owners and renters, how does disability status shape household neighborhood and housing quality? Table 1 addresses this question, presenting the means for our main dependent variables and focusing on comparisons between renter and owner households with and without people with disabilities defined in two ways. Our results show that there appears to be significant disability status disparities among renters and owners, but there are fewer significant disparities among the former group. More specifically, among renters, comparing columns 1 and 2 reveals that 11.46 percent of disabled, renter households report the presence of abandoned buildings in their neighborhoods, compared to 8.25 percent of non-disabled, renter households. In addition, households with people with disabilities are significantly more likely to report crime in their neighborhoods; individuals and/or families with disabilities live in moderately or severely inadequate housing compared to those without. Columns 3 and 4 reveal that restricting our definition of disability status to only consider persons with ambulatory disabilities reduces the number of disability status residential disparities. About 11.5 percent of households that have at least one person with an ambulatory disability report the presence of abandoned buildings in their neighborhoods, compared to nearly 8.5 percent of households without people with disabilities defined in this manner. However, no other significant differences exist.

Table 1. Residential Attainment of Households with and without Disabled Persons by Housing Tenure, 2009.

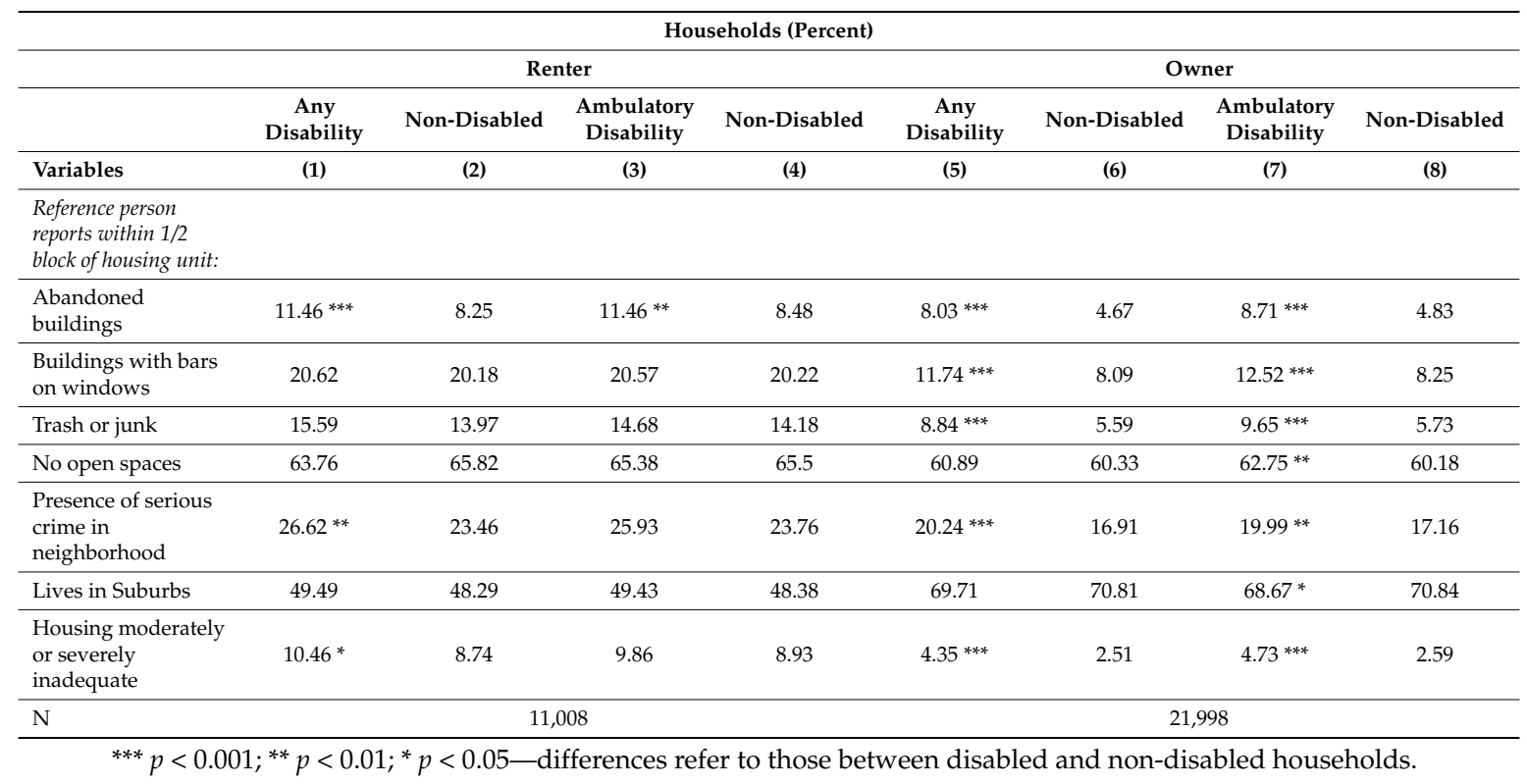

Table 1 shows that among owners, there are a greater number of disability status residential disparities, regardless of the way in which disability is defined. Comparing the results in columns 5 and 6 reveals that owner households with at least one disabled person experience significantly poorer neighborhood and housing outcomes than households without people with disabilities on all dimensions, except for indicators of whether there are open spaces in the neighborhoods and whether the housing unit is in the suburbs.

In other words, among owners, households with people with disabilities are significantly more likely than households without people with disabilities to report the presence of abandoned buildings, buildings with bars on windows, trash or junk, and crime in the neighborhoods. When considering households with at least one person experiencing an ambulatory disability relative to those without such persons (i.e., columns 7 and 8), we find that households with people with disabilities are significantly disadvantaged on all dimensions of neighborhood and housing quality relative to households without people with disabilities. 
Table 2 presents group differences in relevant demographic and socioeconomic characteristics for renter (columns 1-4) and owner (columns 5-8) households. As in Table 1, significance tests are presented to evaluate two sets of disability status differences in neighborhood and housing conditions among owners and renters. Despite the fact that, among renters, there are fewer significant residential disadvantages for households with people with disabilities, relative to households without people with disabilities, as compared to owners, the characteristics of renters and owners are remarkably similar. The most notable differences are those in terms of race, receipt of housing assistance, and average duration in the unit. More specifically, among renter households, there is no difference in the percentage of black people between households with and without people with disabilities (columns 1-4). However, among owners, a significantly greater percentage of households with people with disabilities is black -either with any disability (column 5) or with an ambulatory disability (column 6) -relative to households without people with disabilities. Perhaps the slight over-representation of blacks among owner households with people with disabilities causes them to experience poorer quality residential outcomes because blacks experience more residential inequality than other racial and ethnic groups, resulting from their higher levels of residential segregation.

Table 2. Demographic and Socioeconomic Characteristics of Households by Disability Status and Housing Tenure, 2009.

\begin{tabular}{|c|c|c|c|c|c|c|c|c|}
\hline \multicolumn{9}{|c|}{ Households (Percent) } \\
\hline & \multicolumn{4}{|c|}{ Renter } & \multicolumn{4}{|c|}{ Owner } \\
\hline & $\begin{array}{c}\text { Any } \\
\text { Disability }\end{array}$ & Non-Disabled & $\begin{array}{c}\text { Ambulatory } \\
\text { Disability }\end{array}$ & Non-Disabled & $\begin{array}{c}\text { Any } \\
\text { Disability }\end{array}$ & Non-Disabled & $\begin{array}{l}\text { Ambulatory } \\
\text { Disability }\end{array}$ & Non-Disabled \\
\hline Variables & (1) & (2) & (3) & (4) & (5) & (6) & (7) & (8) \\
\hline \multicolumn{9}{|l|}{ Race/ethnicity } \\
\hline White & $59.17^{* * *}$ & 51.43 & $59.91 * * *$ & 51.91 & $78.38^{* *}$ & 76.33 & 76.76 & 76.64 \\
\hline Black & 22.12 & 21.85 & 23.49 & 21.73 & 10.46 ** & 8.80 & $12.69 * * *$ & 8.68 \\
\hline Hispanic & $16.39^{* * *}$ & 21.17 & $14.75 * * *$ & 21.00 & 9.14 & 10.10 & 9.03 & 10.05 \\
\hline Asian & $2.32 * * *$ & 5.55 & $1.85^{* * *}$ & 5.36 & $2.02 * * *$ & 4.76 & $1.53 * * *$ & 4.63 \\
\hline \multicolumn{9}{|l|}{ Householder } \\
\hline \multicolumn{9}{|l|}{ Variables } \\
\hline Native-Born & $12.03^{* * *}$ & 22.83 & $10.43^{* * *}$ & 22.22 & $9.09 * * *$ & 13.38 & $8.14^{* * *}$ & 13.19 \\
\hline Age (mean) & $55.84^{* * *}$ & 39.72 & $60.65^{* * *}$ & 40.37 & $64.08 * * *$ & 50.15 & $66.25^{* * *}$ & 50.87 \\
\hline Male & $37.60 * * *$ & 49.55 & $36.44 * * *$ & 48.82 & $52.86 * * *$ & 58.62 & $49.89^{* * *}$ & 58.54 \\
\hline Married HH & $23.33 * * *$ & 29.69 & $22.15^{* * *}$ & 29.36 & $56.69^{* * *}$ & 65.14 & $53.85^{* * *}$ & 64.86 \\
\hline Kids under 18 & $27.03^{* * *}$ & 36.64 & $18.34 * * *$ & 36.87 & $20.95^{* * *}$ & 38.20 & $15.26^{* * *}$ & 37.63 \\
\hline \multicolumn{9}{|l|}{ Education } \\
\hline$<$ h.s. degree & $28.10 * * *$ & 16.15 & $29.58 * * *$ & 16.85 & $18.79 * * *$ & 7,86 & $20.41^{* * *}$ & 8.43 \\
\hline h.s. degree & $31.88^{* * *}$ & 27.61 & $31.96 * * *$ & 27.91 & $30.12 * * *$ & 22.45 & $31.53^{* * *}$ & 22.82 \\
\hline$>$ h.s. degree & $40.02 * * *$ & 56.24 & $38.47 * * *$ & 55.24 & $51.08^{* * *}$ & 69.68 & $48.06^{* * *}$ & 68.75 \\
\hline \multicolumn{9}{|l|}{ Receipt of: } \\
\hline Public assistance & $7.10^{* * *}$ & 3.26 & $7.18^{* * *}$ & 3.53 & $1.41 * * *$ & 0.431 & $1.47^{* * *}$ & 0.491 \\
\hline Disability income & $32.53 * * *$ & 5.60 & $34.88 * * *$ & 7.29 & $19.15^{* * *}$ & 3.92 & $22.31^{* * *}$ & 4.62 \\
\hline Housing asst. & $27.73 * * *$ & 9.20 & $30.57^{* * *}$ & 10.23 & $\mathrm{~N} / \mathrm{A}^{\mathrm{a}}$ & $\mathrm{N} / \mathrm{A}$ & $\mathrm{N} / \mathrm{A}$ & $\mathrm{N} / \mathrm{A}$ \\
\hline Tot. hhinc (mean) & $26.86^{* * *}$ & 43.68 & $24.68 * * *$ & 42.70 & $57.70 * * *$ & 89.94 & $51.60 * * *$ & 88.40 \\
\hline \multicolumn{9}{|l|}{$\begin{array}{l}\text { Time in } \\
\text { unit/location }\end{array}$} \\
\hline Duration in unit & $6.25^{* * *}$ & 4.04 & $6.93^{* * *}$ & 4.12 & $20.96^{* * *}$ & 12.63 & $22.55^{* * *}$ & 13.03 \\
\hline Located in suburb & 49.49 & 48.29 & 49.43 & 48.38 & 69.71 & 70.81 & $68.67 *$ & 70.84 \\
\hline \multicolumn{9}{|l|}{ Region } \\
\hline Northeast & 22.45 & 21.21 & 23.50 & 21.19 & 18.82 & 19.75 & 18.53 & 19.72 \\
\hline South & 32.48 & 33.74 & 32.34 & 33.66 & $37.95^{* *}$ & 35.36 & $40.35^{* * *}$ & 35.29 \\
\hline Midwest & 20.04 & 18.45 & 20.25 & 18.54 & 22.24 & 22.39 & 21.86 & 22.42 \\
\hline West & 25.04 & 26.60 & 23.91 & 26.60 & $20.99^{*}$ & 22.49 & $19.26^{* * *}$ & 22.57 \\
\hline $\mathrm{N}$ & \multicolumn{4}{|c|}{11,008} & \multicolumn{4}{|c|}{21,998} \\
\hline
\end{tabular}

With respect to the receipt of housing assistance, it is notable that among renters, households with people with disabilities, defined in both ways, are three times more likely than households without people with disabilities to receive housing assistance. For example, 27.73 percent of households with any disability received housing assistance compared to 9.2 percent of households without people with disabilities. Owners do not receive assistance, and perhaps the greater residential disparities that exist among owner households with people with disabilities relate to this lack of additional funds to better their residential circumstances. 
The magnitude of the disability status disparities in the average number of years that households reside in their units is remarkably different between renters and owners. Among renters, individuals/families with people with disabilities live in their homes for an average of 6.25 years; that is just over 2 years more than households without people with disabilities. However, among owners, individuals/families with people with disabilities live in their homes for an average of 20.96 years; that is more than 8 years longer than households without people with disabilities. Perhaps this disparity in duration in the home, therefore, explains why disability status residential disadvantages are more prominent among owners compared to renters.

With respect to the other demographic, socioeconomic, and unit characteristics, the disability status differences among renters and owners are quite similar, and therefore, we summarize the general trends in these patterns. With respect to race and ethnicity, households with people with disabilities are more likely than households without people with disabilities to be headed by white householders, and less likely to be headed by Hispanic and Asian householders, regardless of housing tenure. In terms of other demographic characteristics, in general, households with people with disabilities are less likely to be headed by foreign-born individuals, males, those that are married, and with children; they are significantly more likely to be older than households without people with disabilities, although the disability status gap in age is not larger among owners, as suggested in the literature review section.

With regards to socioeconomic variables, households with people with disabilities are less likely than households without people with disabilities to be headed by householders with more than a high school degree. In addition, households with people with disabilities are more likely than households without people with disabilities to receive public assistance and disability income. Their total income is significantly lower than that of households without people with disabilities. Thus, regardless of housing tenure, households with people with disabilities are much more disadvantaged in terms of their socioeconomic resources than households without people with disabilities.

Table 2 reports that the differences in the locational characteristics of the housing units in which households with and without people with disabilities live are minimal. Among owners, those with ambulatory disabilities are less likely than households without people with disabilities to live in the suburbs, although the magnitude of this difference is quite small (68.67 percent vs. 70.84 percent); no such differences exist for renters. In a similar pattern, no regional differences between households with and without people with disabilities exist in terms of location, but for owners, there are significant but very small differences. Owner households with people with disabilities are slightly more likely than owner households without people with disabilities to live in the South, but less likely to live in the West.

Controlling for relevant demographic, socioeconomic, and unit-based characteristics, does disability status continue to shape the residential attainment of renters and owners? Table 3 summarizes the key results from our logistic regression analyses that address this question. Logistic regression models were fitted for the dependent variables in each of the rows in Table 3 (OLS was used). Two sets of models were fitted for each dependent variable for renters and owners. One set was done defining disability status on the basis of whether households had at least one person with any type of disability (versus not). The other set was fitted defining disability status on the basis of whether households contained at least one person with an ambulatory disability (versus not). We control for the characteristics shown in Tables 4 and 5 for renters and owners, respectively. 
Table 3. Odds Ratios and Significance from Multivariate Models Assessing the Impact of Disability Status on Residential Attainment, 2009.

\begin{tabular}{|c|c|c|c|c|}
\hline \multicolumn{5}{|c|}{ Households (Odds Ratios) } \\
\hline & \multicolumn{2}{|r|}{ Renter } & \multicolumn{2}{|r|}{ Owner } \\
\hline & Any Disability & Ambulatory Disability & Any Disability & Ambulatory Disability \\
\hline Variables & (1) & (2) & (3) & (4) \\
\hline \multicolumn{5}{|l|}{$\begin{array}{l}\text { Reference person reports within } \\
1 / 2 \text { block of housing unit: }\end{array}$} \\
\hline Abandoned buildings & $1.40^{* * *}$ & $1.40^{* *}$ & $1.72 * * *$ & $1.70^{* * *}$ \\
\hline $\begin{array}{l}\text { Buildings with bars on } \\
\text { windows }\end{array}$ & 0.98 & 0.97 & $1.37^{* * *}$ & $1.33^{* * *}$ \\
\hline Trash or junk & $1.23 *$ & 1.19 & $1.74^{* * *}$ & $1.79 * * *$ \\
\hline No open spaces & 0.91 & 1.00 & 0.93 & 1.00 \\
\hline $\begin{array}{l}\text { Presence of serious crime in } \\
\text { neighborhood }\end{array}$ & $1.36^{* * *}$ & $1.34^{* * *}$ & $1.46^{* * *}$ & $1.38^{* * *}$ \\
\hline Lives in Suburbs & 1.01 & 1.01 & 0.96 & 0.0 .94 \\
\hline $\begin{array}{l}\text { Housing moderately or } \\
\text { severely inadequate }\end{array}$ & $1.33^{* *}$ & 1.21 & $1.57^{* * *}$ & $1.56^{* * *}$ \\
\hline $\mathrm{N}$ & \multicolumn{2}{|r|}{11,008} & \multicolumn{2}{|r|}{21,998} \\
\hline
\end{tabular}

Overall, the results from the multivariate analyses are consistent with those found in the bivariate analyses presented in Table 1 . There are fewer disability status residential disadvantages among renters relative to owners. Column 1 shows that among renters, the odds of households with at least one person with any type of disability reporting the presence of abandoned buildings in their neighborhoods are 1.4 times the odds of households without people with disabilities, controlling for relevant variables. Column 2 shows the exact same disadvantage for renters' households with people with disabilities based upon the presence of at least one person with an ambulatory disability, relative to households without people with disabilities. Among renter households, columns 1 and 2 also reveal that households with people with disabilities (defined in either way) are significantly more likely to report crime in their neighborhoods, relative to households without people with disabilities, controlling for demographic, socioeconomic, and unit locational characteristics. Column 1 shows that among households with at least one person that has any type of disability, there are two other residential disadvantages. The odds of households with people with disabilities reporting the presence of trash or junk in their neighborhoods and of having moderate or severe housing inadequacies are 1.23 and 1.33 times the odds, respectively, of households without people with disabilities, controlling for relevant factors. However, the odds ratios for these variables are not significant for differences between households with people with an ambulatory disability compared to those without people with an ambulatory disability. Interestingly, most of the differences observed here hardly changed in magnitude with the addition of the demographic, socioeconomic, and unit locational characteristics (analyses not shown).

Among owners, Table 3 shows that households with people with disabilities of either type are significantly more disadvantaged than households without people with disabilities on all residential dimensions, except regarding the variables indicating a lack of open spaces and the unit being in suburbs, controlling for relevant factors (see columns 3 and 4). Most notable are the significant disability status differences found for the outcomes (i) abandoned buildings, (ii) trash or junk, and (iii) moderately or severely inadequate housing. Controlling for relevant demographic, socioeconomic, and unit locational characteristics, among owners, the odds of households with people with disabilities (defined as having any type of disability) reporting the presence of abandoned buildings, trash or junk in their neighborhoods, or living in moderately or severely inadequate housing were 1.72, 1.74, and 1.57 times the odds, respectively, of households without people with disabilities. Results that are similar in magnitude were found for households with a member experiencing an 
ambulatory disability relative to those with household members without any ambulatory disabilities. As in the case with renters, the residential disadvantages experienced by households with people with disabilities of any type are reduced very little after controlling for relevant demographic, socioeconomic, and unit locational characteristics (results not shown). Clearly, there are other factors influencing the existence of these disparities that are not taken into account in our analyses here.

Tables 4 and 5 show the full models from which the odds ratios in Table 3 for the disability coefficients were obtained. Both sets of results address the question of how does disability status shape the residential attainment of renters and owners, respectively, while controlling for relevant socioeconomic and demographic characteristics by presenting the results of logistic and OLS models predicting our neighborhood conditions. Among renters, the results shown in Table 4 indicate a persistent effect of the presence of any disability on the locational attainment of households, even in the presence of controls for other relevant factors.

Table 4 shows that households with people with disabilities of either type are significantly more disadvantaged than households without people with disabilities on most of the residential dimensions, with the exception of the variables indicating bars on the windows, lack of open spaces, and the unit being in suburbs, controlling for relevant factors among renters. Controlling for relevant demographic, socioeconomic, and unit locational characteristics, among renters, households with people with disabilities (defined as having any type of disability) were more likely to report the presence of abandoned buildings, trash or junk in their neighborhoods, or living in moderately or severely inadequate housing compared to households without people with disabilities.

Table 5 shows that among owners, households with people with disabilities of either type are significantly more disadvantaged than households without people with disabilities on all residential dimensions, except the variables indicating a lack of open spaces and the unit being in the suburbs, controlling for relevant factors. Controlling for relevant demographic, socioeconomic, and unit locational characteristics, among owners, households with people with disabilities (defined as having any type of disability) were more likely to report the presence of abandoned buildings, trash or junk in their neighborhoods, or living in moderately or severely inadequate housing compared to households without people with disabilities. The results of Tables 4 and 5 confirm the findings in Tables 1 and 3 showing that there are fewer disability-status residential disadvantages among renters relative to owners. 
Table 4. Logistic Regression Models of Residential Attainment of Renter Households, 2009 (weighted).

\begin{tabular}{|c|c|c|c|c|c|c|c|c|c|c|c|c|c|c|}
\hline \multirow[b]{2}{*}{ Variables } & \multicolumn{2}{|c|}{ Abandoned Buildings } & \multicolumn{2}{|c|}{ Bars on Windows } & \multicolumn{2}{|c|}{ Trash } & \multicolumn{2}{|c|}{ No Open Spaces } & \multicolumn{2}{|c|}{ Serious Crime } & \multicolumn{2}{|c|}{ Suburban Location } & \multicolumn{2}{|c|}{ Housing Inadequacy } \\
\hline & (1) & (2) & (3) & (4) & (5) & (6) & (7) & (8) & (9) & (10) & (11) & (12) & (13) & (14) \\
\hline \multicolumn{15}{|l|}{$\begin{array}{l}\text { Disability Status } \\
\text { Person in hh with: }\end{array}$} \\
\hline Any disability & $\begin{array}{c}1.399 * * * \\
(1.151,1.701)\end{array}$ & $\begin{array}{l}\mathrm{N} / \mathrm{A}^{\mathrm{a}} \\
\mathrm{N} / \mathrm{A}\end{array}$ & $\begin{array}{c}0.975 \\
.833,1.140)\end{array}$ & $\mathrm{N} / \mathrm{A}$ & $\begin{array}{c}1.227 * * \\
(1.039,1.449)\end{array}$ & & $\begin{array}{c}0.907 \\
(0.803,1.024)\end{array}$ & $\mathrm{N} / \mathrm{A}$ & $\begin{array}{c}1.355 \text { *** } \\
(1.183,1.553)\end{array}$ & $\mathrm{N} / \mathrm{A}$ & $\begin{array}{c}1.009 \\
.896 .1 .136)\end{array}$ & $\mathrm{N} / \mathrm{A}$ & $\begin{array}{c}1.329 * * \\
(1.093,1.617)\end{array}$ & $\mathrm{N} / \mathrm{A}$ \\
\hline Ambulatory dis. & N/A & $\begin{array}{c}1.404 * * \\
(1.108,1.777)\end{array}$ & N/A & $\begin{array}{c}0.968 \\
(0.800,1.171)\end{array}$ & & $\begin{array}{c}1.189 \\
(0.967,1.461)\end{array}$ & N/A & $\begin{array}{c}0.991 \\
(0.853,1.152)\end{array}$ & $\mathrm{N} / \mathrm{A}$ & $\begin{array}{c}1.343 * * * \\
(1.136,1.588)\end{array}$ & N/A & $\begin{array}{c}1.013 \\
(0.877,1.171)\end{array}$ & $\mathrm{N} / \mathrm{A}$ & $\begin{array}{c}1.212 \\
(0.952,1.544)\end{array}$ \\
\hline \multicolumn{11}{|l|}{$\begin{array}{l}\text { Racelethnicity (ref. white) } \\
\text { Black }\end{array}$} & & & & \\
\hline 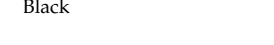 & $\begin{array}{c}2.214, * * * \\
(1.873,2.618)\end{array}$ & $(1.1852,2.586)$ & $(1.952,2.560)$ & $(1.953,2.560)$ & $(1.179,1.569)$ & $(1.170,1.556)$ & $(1.109,1.378)$ & $(1.116,1.386)$ & $(1.177,1.488)$ & $(1.164,1.472)$ & $\begin{array}{c}0.520 \\
(0.476,0.586)\end{array}$ & $\begin{array}{c}0.528 \\
(0.476,0.586)\end{array}$ & $\begin{array}{c}1.130 \\
(0.949,1.352)\end{array}$ & $(0.938,1.336)$ \\
\hline Hispanic & $1231 * *$ & $1.324 *$ & $2.074^{* * *}$ & $2.074^{* * *}$ & 1.128 & 1.12 & $1.285^{* * *}$ & & 1. & & & & & \\
\hline & l.073, 1.658) & $(1.066,1.646)$ & $(1.785,2.410)$ & $(1.785,2.410)$ & $1.952,1.337)$ & $(0.948,1.332)$ & $(1.130,1.460)$ & $(1.133,1.463)$ & $(0.983,1.303)$ & $(0.978,1.296)$ & $(0.488,0.622)$ & $(0.488,0.622)$ & $(0.971,1.451)$ & $(0.966,1.444)$ \\
\hline Asian & 0.656 & 0.653 & $1.571^{* * *}$ & $1.572 * * *$ & 0.836 & & $1.366 * *$ & & 0.853 & 0.849 & & $0.596^{* * *}$ & & \\
\hline & $(0.392,1.098)$ & $(0.010,1.100)$ & $(1.241,1.991)$ & $(1.241,1.991)$ & $(0.612,1.143)$ & $(0.610,1.138)$ & $(1.098,1.700)$ & $(1.102,1.706)$ & $(0.665,1.095)$ & $(0.662,1.089)$ & $(0.490,0.726)$ & $(0.490,0.726)$ & $(0.705,1.399)$ & $(0.700,1.389)$ \\
\hline $\begin{array}{l}\text { Hosusenolder v } \\
\text { Native-Bor }\end{array}$ & $0.641^{* * *}$ & $0.637^{* * *}$ & $1.358^{* * *}$ & $1.358 * * *$ & 0.923 & 0.917 & $1.429^{* * *}$ & $1.438 * * *$ & 0.793 ** & $0.788^{* * *}$ & 0.915 & 0.91 & 1.105 & 1.092 \\
\hline & $(0.512,0.802)$ & $(0.509,0.796)$ & $(1.180,1.563)$ & $(1.180,1.563)$ & $(0.780,1.091)$ & $(0.775,1.085)$ & $(1.259,1.621)$ & $(1.268,1.632)$ & $(0.689,0.913)$ & & $(0.815,1.029)$ & & & \\
\hline Age & $\begin{array}{l}0.987 * \\
(0.92,0 .\end{array}$ & $\begin{array}{c}0.988 \text { * } \\
(0.983,0 .\end{array}$ & $\begin{array}{c}0.9955^{* *} \\
(0.9911 .998)\end{array}$ & $\begin{array}{c}0.995 \text { ** } \\
(0.991,0.998)\end{array}$ & $\begin{array}{c}0.979 * * * \\
(0.975,0.983)\end{array}$ & $\begin{array}{l}0.979 * * * * \\
(0.975094)\end{array}$ & $\begin{array}{c}1.004 * \\
(1.001 .006)\end{array}$ & $\begin{array}{c}1.003^{*} \\
(1.006106)\end{array}$ & $0.985 * * * *$ & 0.985 **** & $1.010^{* * * *}$ & $1.010^{* * *}$ & $0.990^{* * * *}$ & $0.991 * * *$ \\
\hline \multirow[t]{2}{*}{ Male } & $\begin{array}{l}0.847^{*} \\
0.730 .982\end{array}$ & $\begin{array}{c}0.846^{*} \\
0.729 .982\end{array}$ & $\begin{array}{c}0.988 \\
0.888\end{array}$ & 0.988 & $0.888^{*}$ & $0.887^{*}$ & $\begin{array}{c}0.96 \\
0.06\end{array}$ & 0.962 & $\begin{array}{c}0.900 \\
0.958\end{array}$ & 0.956 & $\begin{array}{c}1.015 \\
0.0361\end{array}$ & $\begin{array}{c}1.015 \\
1.02\end{array}$ & $\begin{array}{l}1.177^{*} \\
\end{array}$ & $1.174^{*}$ \\
\hline & $(0.730,0.982)$ & $(0.729,0.982)$ & $(0.888,1.100)$ & $(0.888,1.100)$ & $\begin{array}{l}(0.79,0.999) \\
0702 * *\end{array}$ & $(0.789,0.998)$ & $(0.882,1.044)$ & $(0.884,1.046)$ & $(0.871,1.054)$ & $\begin{array}{l}(0.869,1.052) \\
086 * *\end{array}$ & $(0.936,1.100)$ & $(0.936,1.100)$ & $(1.023,1.355)$ & $(1.021,1.351)$ \\
\hline Married household & $\begin{array}{c}0.925 \\
07691112\end{array}$ & $\begin{array}{c}0.922 \\
(07671108)\end{array}$ & $0.776^{* * *}$ & $\begin{array}{l}0.776^{* * * *} \\
(0.681 .083)\end{array}$ & $0.792^{* *}$ & 0.791 & 0.5 & & & & & & $(06740949)$ & \\
\hline \multirow{2}{*}{ Kids under 18} & & & & 1. & & 5) & & $\begin{array}{l}(0.831,1, \\
0.859\end{array}$ & & & $\begin{array}{l}(1.183,1.432) \\
1.42 * * *\end{array}$ & $(1.183,1$ & $\begin{array}{c}(0.674,0.949) \\
1,017\end{array}$ & $(0.673,0.949)$ \\
\hline & $(1.002,1.384)$ & $(1.014,1.400)$ & $(0.89,1.137)$ & $(0.889,1.136)$ & $(0.916,1.190)$ & $(0.921,1.197)$ & $(0.780,0.946)$ & $(0.780,0.946)$ & $(1.062,1.316)$ & $(1.071,1.328)$ & $\begin{array}{c}1.422 \\
(1.296,1.561)\end{array}$ & $\begin{array}{r}1.423 \\
(1.296,1.562)\end{array}$ & $\begin{array}{c}1.017 \\
(0.868,1.193)\end{array}$ & $\begin{array}{c}1.0024 \\
(0.873,1.201)\end{array}$ \\
\hline \multirow{2}{*}{$\begin{array}{l}\text { Education (ref <h.s.) } \\
\text { h.s. Degree }\end{array}$} & 0.934 & 0.931 & 0.895 & 0.895 & 0.934 & 0.932 & & 1015 & & & & & & 0.958 \\
\hline & & $(0.76$ & 41) & & & $(0.790$ & $(0.891$ & & & & & & & \\
\hline \multirow[t]{2}{*}{$>$ h.s. Deg } & & & & & & & & & & & & & & \\
\hline & $(0.658,0$. & $(0.655,0.975)$ & $(0.842,1.134)$ & $(0.843,1.135)$ & $(0.713,0.991)$ & $(0.710,0.988)$ & $(0.834,1.070)$ & $(0.837$, & $(1.043$, & $(1.038,1.372)$ & $(0.863,1.095)$ & $(0.863,1)$ & $(0.779$ & $(0.774,1.150)$ \\
\hline \multirow[t]{2}{*}{ Receipt of: Public assistance } & $1.866 * * *$ & $1.879 *$ & 1.319 & 1.319 & $1.758^{* * * *}$ & $1.765 * * * *$ & 0.95 & 0.945 & 1.254 & $1.26^{*}$ & 0.915 & 0.9 & $1.384 *$ & $1.395 *$ \\
\hline & $(1.435,2.428)$ & $(1.445,2.4$ & $(1.036,1.68$ & $(1.035,1.6$ & $(1.392,2.2)$ & $(1.397,2.23)$ & $(0.767,1.176)$ & $(0.763,1.170)$ & $(1.006,1.5$ & $(1.01,1$. & $(0.742,1.128)$ & $(0.742,1$ & $(1.026,1.866)$ & $(1.035,1.880)$ \\
\hline \multirow[t]{2}{*}{ Disability income } & 1.211 & $1.259 *$ & $1.253 *$ & $1.250 * *$ & $1.299 * *$ & $1.340^{* *}$ & 0.988 & 0.96 & $1.195 *$ & $1.242 * *$ & 0.989 & 0.99 & 1.156 & 1.218 \\
\hline & $(0.974,1.5$ & $(1.016,1.559)$ & $(1.053,1.491)$ & $(1.054,1.484)$ & $(1.079,1.564)$ & $(1.117,1.608)$ & $(0.854,1.142)$ & $(0.832,1.1$ & $(1.021,1.400)$ & $(1.063,1.451)$ & & & $(0.922,1.448)$ & $(0.975,1.520)$ \\
\hline \multirow[t]{2}{*}{ Housing asst. } & $\begin{array}{r}0.836 \\
0.6310\end{array}$ & $\begin{array}{r}0.844 \\
0.69010\end{array}$ & $\begin{array}{r}1.029 \\
087912\end{array}$ & $\begin{array}{r}1.029 \\
0878.12\end{array}$ & $\begin{array}{r}0.98 \\
0825\end{array}$ & $\begin{array}{r}0.988 \\
083211\end{array}$ & 0.812 ** & $0.805 * *$ & $\begin{array}{l}1.156 \\
1.56\end{array}$ & $1.166^{*}$ & $0.712 * * *$ & 0.712 & 1.034 & $\begin{array}{l}1.049 \\
0511\end{array}$ \\
\hline & $(0.683,1, x)$ & $(0.690,1.0$ & $(0.879,1.2)$ & $(0.878,1.2$ & $(0.825,1.1)$ & $(0.832,1.1)$ & $(0.710,0.929)$ & & $(0.999,1.337)$ & $(1.008$, & & & $(0.838$ & $(0.851,1.294)$ \\
\hline Total hh income & & 0.994 & 0.99 & $\begin{aligned} 0.9 \\
0\end{aligned}$ & & 0.99 & 0.998 & 0.99 & 1 & & & & $\begin{array}{c}0.999 \\
0.997 \\
0\end{array}$ & 0097101010 \\
\hline & $(0.991,0.997)$ & $(0.991,0.997)$ & $(0.997,1.000)$ & $(0.997,1.0$ & $(0.994,0.998)$ & $(0.994,0.998)$ & 0.997 & $(0.997,0.999)$ & $(0.999,1.001)$ & $(0.999,1.001)$ & $(1,1.003)$ & $(1,1.003)$ & $(0.997,1.001)$ & $(0.997,1.001)$ \\
\hline Duration in unit & & & & & & & & & & & & & & \\
\hline & & & & & & & & & & & & & & \\
\hline Located in suburb & & & & & & & & & & & & & & \\
\hline Region (ref. & $(0.4,0.54)$ & $(0.4,0.539)$ & $(0.237,0.297)$ & $(0.237,0.297)$ & $(0.479,0.605)$ & $(0.479,0.605)$ & $(0.620,0.729)$ & $(0.619,0.729)$ & $(0.485,0.584)$ & $(0.485,0.584)$ & $(\mathrm{N} t$ & $(\mathrm{N}$ & $(0.545,0.720)$ & $(0.546,0.720)$ \\
\hline Northeast & & 1.213 & & & & & & & $0.731^{* * *}$ & $0.729^{* * *}$ & $0.801 * * *$ & $0.800 *$ & 1.521 & \\
\hline & $(0.987,1.498)$ & & $(0.866,1.134)$ & $(0.866,1.1$ & $(0.885,1.214)$ & $(0.884,1.212)$ & $(0.808,1.027)$ & $(0.809$, & $(0.636$, & $(0.635$, & $(0.714$, & $(0.714$, & & $(1.26,1.827)$ \\
\hline South & 0.984 & 0 & & $0.4322^{*}$ & 0.695 *** & $0.695 * * *$ & $0.879 *$ & 0.87 & 0.99 & $\begin{array}{r}0.9 \\
0877\end{array}$ & $\begin{array}{r}1.0 \\
0.0\end{array}$ & 1.0 & 0.8 & $\begin{array}{l}0.871 \\
070\end{array}$ \\
\hline & $(0.811,1.1$ & $(0.810,1$. & $(0.377,0$. & $(0.377, \mathrm{c})$ & $(0.598,0.8$ & $(0.598,0.808)$ & $(0.788,0.97$ & $(0.788$, & $(0.877,1$ & $(0.877$ & $(0.969$, & $(0.969$, & $(0.723$, & $(0.723$, \\
\hline Midwest & 1.174 & 1.171 & 0.339 *** & $0.339^{\circ}$ & 0.907 & 0.906 & $0.748 * *$ & 0.748 & 1.012 & 1.012 & 0.837 ** & 0.8 & 1.0 & 1.0 \\
\hline & $(0.947$, & $(0.945$, & $(0.285$, & $(0.285$ & $(0.767$ & $(0.767$ & $(0.661,0.846)$ & $(0.661$, & $(0.882$ & $(0.882$, & $(0.742$, & $(0.742$, & $(0.867$ & $(0.867$, \\
\hline Intercept & $0.218^{* *}$ & & & $0.481^{* * *}$ & 0.670 ** & 0.675 ** & $2.444^{* * *}$ & $2.454^{* * *}$ & $0.607^{* * *}$ & $0.614^{* * *}$ & 0.736 ** & $0.736^{* *}$ & $0.154^{* * *}$ & $0.154 * * *$ \\
\hline 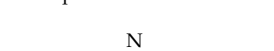 & & & & & & & $\begin{array}{c}(1.978,3.021) \\
11\end{array}$ & $(1.986,3.033)$ & $(0.479,0.770)$ & $(0.484,0.778)$ & $(0.602,0.899)$ & $(0.602,0.899)$ & $(0.109,0.217)$ & $(0.108,0.218)$ \\
\hline
\end{tabular}

Notes: ${ }^{a} \mathrm{~N} / \mathrm{A}$ designates results are not applicable to this category; ${ }^{* * *} p<=0.01 ;{ }^{* *} p<0.05 ;{ }^{*} p<0.10$. 
Table 5. Logistic Regression Models of Residential Attainment of Owner Households, 2009 (weighted).

\begin{tabular}{|c|c|c|c|c|c|c|c|c|c|c|c|c|c|c|}
\hline \multirow[b]{2}{*}{ Variables } & \multicolumn{2}{|c|}{ Abandoned Buildings } & \multicolumn{2}{|c|}{ Bars on Windows } & \multicolumn{2}{|c|}{ Trash } & \multicolumn{2}{|c|}{ No Open Spaces } & \multicolumn{2}{|c|}{ Serious Crime } & \multicolumn{2}{|c|}{ Suburban Location } & \multicolumn{2}{|c|}{ Housing Inadequacy } \\
\hline & (1) & (2) & (3) & (4) & (5) & (6) & (7) & (8) & (9) & (10) & (11) & (12) & (13) & (14) \\
\hline \multicolumn{15}{|l|}{$\begin{array}{l}\text { Disability Status } \\
\text { Person in hh with: }\end{array}$} \\
\hline & $\begin{array}{c}1.721 * * * \\
(1.464,2.025)\end{array}$ & $\mathrm{N} / \mathrm{A}^{\mathrm{a}}$ & $\begin{array}{c}1.368 \text { *** } \\
(1.187,1.576)\end{array}$ & N/A & $\begin{array}{c}1.739 * * * \\
(1.494,2.025)\end{array}$ & $\mathrm{N} / \mathrm{A}$ & $\begin{array}{c}0.933 \\
(0.858,1.014)\end{array}$ & N/A & $\begin{array}{c}1.462 * * * \\
(1.319,1.622)\end{array}$ & N/A & $\begin{array}{c}0.959 \\
(0.877,1.049)\end{array}$ & N/A & $\begin{array}{c}1.57 * * * \\
(1.268,1.945)\end{array}$ & $\mathrm{N} / \mathrm{A}$ \\
\hline Ambulatory dis. & N/A & $\begin{array}{c}1.702 * * * \\
(1.409,2.055)\end{array}$ & N/A & $\begin{array}{c}1.329 * * \\
(1.125,1.570)\end{array}$ & N/A & $\begin{array}{c}1.793 * * * \\
(1.500,2.142)\end{array}$ & N/A & $\begin{array}{c}1.004 \\
(0.907,1.112)\end{array}$ & N/A & $\begin{array}{c}1.376 * * \\
(1.213,1.561)\end{array}$ & N/A & $\begin{array}{c}0.935 \\
(0.839,1.041)\end{array}$ & N/A & $\begin{array}{c}1.555 * * * \\
(1.215,1.991)\end{array}$ \\
\hline \multicolumn{15}{|l|}{ Race/ethn (ref. whi } \\
\hline Black & $\begin{array}{c}2.709^{* * *} \\
(2.301,3.188)\end{array}$ & $(2.267,3.139)$ & $(3.228,4.270)$ & $(3.200,4.232)$ & $(1.354,1.895)$ & $(1.334,1.866)$ & $(1.127,1.384)$ & $(1.128,1.386)$ & $\begin{array}{c}1 . .50 \\
(1.211,1.527)\end{array}$ & $\begin{array}{c}1.540 \\
(1.201,1.513)\end{array}$ & $(0.339,0.413)$ & $(0.339,0.413)$ & $\begin{array}{l}1.030 \\
(1.306,2.105)\end{array}$ & $(1.29,2.078)$ \\
\hline Hispanic & $1.531^{* * *}$ & $1.518^{* * *}$ & $3.173 * * *$ & $3.155 * * *$ & $\begin{array}{l}1.209 \\
090.147)\end{array}$ & $\begin{array}{c}1.199 \\
(0.92\end{array}$ & $\begin{array}{c}1.600 * * * \\
(1428\end{array}$ & $1.601 * * *$ & 1.17 & $\begin{array}{r}1.19 \\
1.044\end{array}$ & $0.564 * * *$ & 0.56 & $1.827 * * *$ & $\begin{array}{l}1.818 \text { *** } \\
(1.389238)\end{array}$ \\
\hline Asian & $\begin{array}{c}0.527^{*} \\
(0.319,0.871)\end{array}$ & $\begin{array}{c}0.522 * * \\
(0.316,0.863)\end{array}$ & $\begin{array}{c}1.211 \\
(0.929,1.579)\end{array}$ & $\begin{array}{c}1.205 \\
(0.925,1.571)\end{array}$ & $\begin{array}{c}0.871 \\
(0.615,1.233)\end{array}$ & $\begin{array}{c}(0.962,1.460) \\
0.863 \\
(0.610,1.222)\end{array}$ & $\begin{array}{c}1.4268 * * \\
1.268 * \\
(1.080,1.49)\end{array}$ & $\begin{array}{c}(1.42 .1 .1 .15) \\
1.269 * * \\
(1.080,1.492)\end{array}$ & $\begin{array}{c}0.04885 * * \\
0.547 \\
(0.545,0.861)\end{array}$ & $\begin{array}{c}0.682 * * * \\
0.543,0.8577) \\
(0.543,0.00\end{array}$ & $\begin{array}{c}(0.500,0.027) \\
0.774 * * \\
(0.66,0.909)\end{array}$ & $\begin{array}{c}(0.300,0.027) \\
0.775 \text { ** } \\
(0.66,0.91)\end{array}$ & $\begin{array}{c}(1.590,2.39) \\
1.079 \\
(0.640,1.818)\end{array}$ & $\begin{array}{c}(1.039,1.20) \\
1.073 \\
(0.637,1.808)\end{array}$ \\
\hline \multicolumn{15}{|l|}{ Householder Vars } \\
\hline Native & $\begin{array}{c}0.703^{* *} \\
(0.559,0.884)\end{array}$ & $(0.555,0.877)$ & $(1.158,1.58)$ & $(1.153,1.573)$ & $\begin{array}{c}0.821 \\
(0.667,1.010)\end{array}$ & $(0.664,1.005)$ & $(1.192,1.471)$ & $(1.193,1$. & $\begin{array}{c}0.752^{2 * *} \\
(0.656,0.862)\end{array}$ & $(0.652,0$. & $\begin{array}{r}0.869^{* *} \\
(0.782,0.9\end{array}$ & $\begin{array}{c}0.869^{* *} \\
(0.782,0.965)\end{array}$ & $\begin{array}{c}0.876 \\
(0.661,1.162)\end{array}$ & $\begin{array}{c}0.871 \\
(0.657,1.155)\end{array}$ \\
\hline Age & & 0.9790 & $0.986^{* * *}$ & & 0.972 & & & & & & & & & \\
\hline & $(0.973,0$. & $(0.974,0.984)$ & $(0.982,0.991)$ & $(0.982,0.991)$ & $(0.967,0.976)$ & $(0.968,0.977)$ & $(0.999,1.004)$ & $(0.998,1.003)$ & & & & & & \\
\hline Male & & & & & & & & & & & & & & \\
\hline Married household & 248) & $\begin{array}{l}(0.964,1.249) \\
0.874\end{array}$ & $\begin{array}{l}(0.927,1.152) \\
0.710 * *\end{array}$ & $\begin{array}{l}(0.927,1.1 .153) \\
0.700 * * *\end{array}$ & $\begin{array}{l}0.870,1.101) \\
0.917\end{array}$ & $\begin{array}{l}(0.872,1.105) \\
0.915\end{array}$ & $\begin{array}{l}(0.909,1.022) \\
0.901 *\end{array}$ & $\begin{array}{l}(0.910,1.023) \\
0.901 *\end{array}$ & $\begin{array}{l}(0.807,0.937) \\
0.988\end{array}$ & $\begin{array}{l}(0.807,0.937) \\
0.987\end{array}$ & $\begin{array}{l}(0.908, \\
1.396\end{array}$ & $\begin{array}{r}0.908 \\
1.39\end{array}$ & $\begin{array}{l}(0.921, \\
0.76\end{array}$ & $\begin{array}{l}(0.923,1.305) \\
0.762 * *\end{array}$ \\
\hline Marmed nousenota & $(0.762,1.007)$ & $\begin{array}{l}(0.760,1.005) \\
\text { (1) }\end{array}$ & $(0.632,0.797)$ & $(0.631,0.796)$ & $(0.807,1.043)$ & $(0.805,1.040)$ & $(0.845,0.962)$ & $(0.845,0.962)$ & $\begin{array}{l}(0.909,1.073) \\
-9.07\end{array}$ & $(0.908$, & (1.303, & (1.303 & $\begin{array}{c}0.104 \\
(0.63,0.919)\end{array}$ & $(0.633,0.918)$ \\
\hline Kids under 18 & 0.971 & & 0.818 & 0.824 & 0.800 & 0.811 & 0.9 & 0.9 & & & & & 0.8 & 91 \\
\hline & \multicolumn{8}{|c|}{ Educatior } & & $(1.079,1.281)$ & $(1.097,1.271)$ & $(1.096,1.27)$ & $(0.720,1.081)$ & $(0.727,1.092)$ \\
\hline h.s. degr & $0.623^{* * *}$ & $0.617^{* * *}$ & $0.733^{* * *}$ & $0.728 * * *$ & $0.772 * *$ & 0.766 ** & 0.991 & & & & & & & $0.595^{* * *}$ \\
\hline$>$ h.s. $d$ & & & & & & & $\begin{aligned}(0.886 \\
0 .\end{aligned}$ & $\begin{aligned}(0.891, & 0.9 \\
0 . & \end{aligned}$ & & & $\begin{array}{l}(1.012,1.276) \\
0.93\end{array}$ & $\begin{array}{l}(1.012,1.275) \\
0.93\end{array}$ & & \\
\hline & $(0.436,0.635)$ & $(0.430,0.627)$ & $(0.581,0.799)$ & $(0.576,0.792)$ & $(0.548,0.794)$ & $(0.542,0.785)$ & $(0.866,1.070)$ & $(0.872,1.079)$ & $(1.018,1.337)$ & $(1.003,1.317)$ & $(0.834,1.037)$ & $(0.834,1.037)$ & $(0.401,0.649)$ & $(0.396,0.641)$ \\
\hline \multicolumn{15}{|l|}{ Receip } \\
\hline Public assistance & $\begin{array}{c}0.72 \\
.374,1.385)\end{array}$ & $\begin{array}{r}0 . \\
(0.373\end{array}$ & $(0.848$, & .853 & .960 & $(0.964$, & $(0.734$ & $\begin{array}{rl}1.0 & 0 \\
(0.727, & \end{array}$ & $(0.530$ & $(0.538$ & $\begin{array}{c}0.666^{*} \\
(0.462,0.959)\end{array}$ & $\begin{array}{c}0.666 \\
(0.462,0.959)\end{array}$ & $\begin{array}{c}1.679 \\
(0.868 .3247)\end{array}$ & $\begin{array}{r}1.68 \\
(0.870\end{array}$ \\
\hline Disability income & $\begin{array}{c}1.227 \\
(0.899\end{array}$ & $\begin{array}{c}1.227^{*} \\
(1.02983)\end{array}$ & $\begin{array}{c}1.189 \\
(0.984\end{array}$ & $\begin{array}{r}1.223 \\
0.013 .1\end{array}$ & $\begin{array}{r}1.103 \\
0.893 .1\end{array}$ & $\begin{array}{r}1.13 \\
0.919 .1\end{array}$ & $\begin{array}{c}0.909 \\
0.808 .1021\end{array}$ & $\begin{array}{c}0.889 * \\
\text { * }\end{array}$ & $\begin{array}{c}1.142 \\
(0900131\end{array}$ & 1.191 * & $\begin{array}{c}1.032 \\
(0.910170)\end{array}$ & $\begin{array}{c}1.035 \\
(0.33)\end{array}$ & $\begin{array}{r}1.0 \\
(0809\end{array}$ & 1.1 \\
\hline Total hh income & $0.996 * * * *$ & 0 & $\begin{array}{l}(0.907,1.457) \\
0.999 *\end{array}$ & $\begin{array}{l}(1.013,1.4 / 7) \\
0.999 *\end{array}$ & $\begin{array}{l}0.05,1.0007) \\
0.997 * * *\end{array}$ & $0.997 * * * 4)$ & $\begin{array}{l}(.000,1.021 \\
1.000^{*}\end{array}$ & (0. & $(0.990,1.31$ & $(1.033,1,1.0 / 4)$ & $(0.910,1.170)$ & (0.0) & $\begin{array}{l}0.099 \\
0.99\end{array}$ & $\begin{array}{l}0.836, \\
0.99\end{array}$ \\
\hline & $(0.995,0.997)$ & $(0.995,0.997)$ & $(0.998,1.000)$ & $(0.998,1.000)$ & $(0.996,0.998)$ & $(0.996,0.998)$ & $(0.999,1.000)$ & $(0.999,1.000)$ & $(1.000,1.001)$ & $(0.999,1.000)$ & $(1.000,1.001)$ & $(1.000,1.001)$ & $(0.996,0.999)$ & $(0.996,0.999)$ \\
\hline \multicolumn{15}{|l|}{ Time in $u$} \\
\hline Duration in unit & $\begin{array}{r}1.008 \\
(1.002,1\end{array}$ & & $\begin{array}{r}1.016,1.02 \\
(1.016,\end{array}$ & $\begin{array}{l}1.021 * 1 \\
(1.017,1.6\end{array}$ & 1.014 & & $\begin{array}{c}1.0057,1.010) \\
(1.005\end{array}$ & 1.007 & & & $(0.990$, & $\begin{array}{l}0.9993 \\
(0.990,\end{array}$ & & \\
\hline \multirow[t]{2}{*}{ Located in suburb } & & & & & & & & & & & & & & \\
\hline & $(0.472,0.607)$ & $(0.472,0.607)$ & $(0.185,0.229)$ & $(0.185,0.229)$ & $(0.437,0.551)$ & $(0.437,0.551)$ & $(0.493,0.561)$ & $(0.494,0.561)$ & $(0.474,0.550)$ & $(0.474,0.550)$ & (NA) & (NA) & $(0.540,0.758)$ & $(0.540,0.758)$ \\
\hline \multirow{2}{*}{$\begin{array}{l}\text { Region (ret. West) } \\
\text { Northeast }\end{array}$} & & & & & & & & & & & & & & \\
\hline & $(0.599,0.908)$ & $(0.595,0.903)$ & $(0.501,0.6$ & $(0.499,0$. & $(0.774,1$ & $(0.770,1)$ & $(0.816$, & $(0.817$, & $(0.615$, & $(0.61$ & & & & \\
\hline \multirow[t]{2}{*}{ South } & & & & & & & & & & & & & & \\
\hline & $(0.642$ & $(0.638$ & & & & $(0.678$ & $(0.929$ & $(0.929$, & $(0.998$ & 206) & & & & \\
\hline \multirow[t]{2}{*}{ Midwest } & & & & & & & & 0.83 & & & & & & \\
\hline & $\left(0.88^{-}\right.$ & & $(0.219$ & $(0.219$ & $(0.700$, & $(0.696$ & $(0.769,0.911)$ & $(0.769$, & $(0.841$, & & $(1.06]$ & $(1.06$ & & \\
\hline \multirow[t]{2}{*}{ Intercept } & & & & & (0.090 & 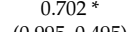 & (2080 1060$)$ & $2.382^{* * *}$ & & & & & & $0.100^{* * *}$ \\
\hline & $(0.681,0.319)$ & $(0.684,0.321)$ & $(0.871,0.461)$ & $(0.872,0.460)$ & $(0.990,0.493)$ & $(0.995,0.495)$ & $(2.869,1.960)$ & $(2.880,1.960)$ & $(0.479,0.773)$ & $(0.476,0.768)$ & $(1.135,1.680)$ & $(1.139,1.687)$ & $(0.059,0.168)$ & $(0.059,0.168)$ \\
\hline 1 & \\
\hline
\end{tabular}

Notes: ${ }^{a} \mathrm{~N} /$ A designates results are not applicable to this category; ${ }^{* * *} p<=0.01 ;{ }^{* *} p<=0.05 ;{ }^{*} p<=0.10$. 


\section{Discussion and Conclusions}

The primary objective of this paper was to examine the nature of disability status differences in residential attainment among renters and owners. To fulfill this overarching goal, the analysis focused on answering three main questions. First, does the disability status of households matter in shaping their neighborhood conditions and housing quality among renters and owners? Our descriptive analyses revealed that disability status shapes residential inequalities more for owners than renters, regardless of how disability is defined. Among owners, households with people with disabilities experience residential disadvantages on almost all residential outcomes (except for the indicator for a lack of open spaces) than households without people with disabilities. However, among renters, fewer disability-status residential disparities are observed.

Second, controlling for relevant socioeconomic and demographic characteristics, to what extent does disability status shape the residential attainment of owners and renters? The results of our logistic regression and OLS models indicated that the nature of the disparities observed in our descriptive analyses were nearly the same as those from our multivariate analyses, indicating that the control variables did little to account for these disability status disparities. Third, is the impact of disability status the same on the residential attainment of both renters and owners? As was the case in the descriptive analyses, among owners, there continues to be more significant disparities in neighborhood and housing conditions for households with people with disabilities, relative to households without people with disabilities, than was the case for renters, controlling for relevant demographic, socioeconomic, and unit-based characteristics. The pattern of the results is the same, despite which disability outcome is used in these analyses.

Taken together, the results here suggest that considering housing tenure is important in understanding disability status residential disadvantages. Theoretically, the findings here support hypotheses from both the spatial assimilation and the discrimination models. With respect to the former, it is clear that socioeconomic status and demographic factors shape the residential attainment of both renters and owners. For households in both housing tenure groups, greater levels of education and income generally translate into better residential outcomes. With respect to demographic factors, married households and those with older householders are more likely than unmarried and younger households, respectively, to reside in better quality neighborhoods and housing. Time in the housing unit, however, is generally associated with poorer neighborhoods and housing conditions.

At the same time, the results revealed that the effect of disability status on residential outcomes persisted among renters and homeowners, even after controlling for the differences in the demographic, socioeconomic, and unit-based characteristics that were evident between households with and without people with disabilities. As mentioned above, controlling for these factors did little to explain the residential disadvantages faced by households with people with disabilities, relative to households without people with disabilities, regardless of whether they were renters or homeowners. These results suggest that there are additional factors beyond those associated with the spatial assimilation model that may explain these differences.

Consistent with the tenets of the discrimination model, it is likely that discrimination in the housing market explains part of the disparities in residential outcomes left unexplained by the spatial assimilation model. As recently as 2017, the largest share of discrimination complaints-61.9 percent of complaints-filed nationally at HUD were made on the basis of disability status (Abedin et al. 2018). Our results revealed that disability status residential disadvantages were more prevalent among homeowners than renters. This finding is consistent with our hypothesis that enforcement of the Fair Housing Act is less prevalent in the sales market than in the rental market. As mentioned above, testing for discrimination is much easier in the rental housing market because rental housing is advertised much more easily and the interactions between renters and landlords are done quickly. Moreover, discrimination in the sales market is usually found in the financing stage of the home purchasing process, and perhaps in securing capital to maintain the upkeep of housing. In both 
instances, these types of discrimination are harder to detect than when landlords refuse to make modifications to their homes for people with disabilities.

Based on the International Classification of Functioning, Disability and Health (ICF), environmental factors ranging from physical factors (such as climate, terrain or building design) to social factors (such as attitudes, institutions, and laws) can be responsible for the disability (WHO 2013). A better understanding of how individuals interact with environmental factors is an essential aspect of understanding 'functioning and disability'; the environmental experiences can facilitate a disability or be a barrier for people with existing disabilities (WHO 2013). One of the major limitations of our study is that our cross-sectional analyses cannot clearly identify the underlying causes of the persistence of disability status disparities in the residential outcomes of renters and owners. Longitudinal data are clearly needed in order to follow people as they become disabled over time and modify their environmental circumstances both as renters and owners.

While we have controlled for the important socioeconomic and demographic variables associated with the spatial assimilation model, we have not controlled for factors that could affect households with people with disabilities' abilities to modify their residential circumstances like social support or other factors that can play a role in facilitating the ability of older homeowners to deal with the upkeep of their homes, as well as being able to sell their homes. Aging and falling into poor health are processes that occur over a long period of time, and knowing more about how these gradual processes shape the residential circumstances will be important in building a stronger theory. In addition, knowing the specific circumstances about the disability status and health of the others in the household could play a role in explaining the residential disadvantages experienced by households with people with disabilities as compared to households without people with disabilities. Having direct information about households' experiences with discrimination would also be extremely useful in understanding these residential inequalities between households with and without people with disabilities.

Our paper clearly raises more questions than it answers, and therefore, serves as a point of departure to build on the current, limited existing literature on the impact of disability status on residential attainment for owners and renters. Here we have offered two theoretical frameworks to structure the analyses of disability status residential inequalities that have heretofore been absent from the existing literature. In addition to employing the use of longitudinal data, future research should pay more attention to the role of fair housing enforcement in shaping the residential attainment of protected groups like those experiencing disabilities. How powerful actors such as housing developers, landlords, and mortgage lenders attempt to segregate households with people with disabilities relative to households without people with disabilities is an important question that needs to be addressed. This is particularly true based on future projections stating that as many as 21 percent of households will have at least one member who is disabled by 2050 (Smith et al. 2008).

Author Contributions: The first two authors, Samantha Friedman and Kaya Hamer-Small, contributed equally to the article. They spent equal time conceiving of the project, writing the paper, and carrying out the analyses. Wendie Choudary made substantive contributions to the original conception and writing of the paper. She also assisted with the initial analyses. Thereafter, she helped with presenting the results of the analyses.

Funding: Support for this research was provided by a grant to the Center for Social and Demographic Analysis at the University at Albany from the Eunice Kennedy Shriver National Institute of Child Health and Human Development (R24 HD044943).

Acknowledgments: We thank Hui-shien Tsao for her programming assistance, and the anonymous reviewers for their helpful comments.

Conflicts of Interest: The authors declare no conflict of interest. 


\section{Appendix A}

Table A1. Total Mean and Standard Deviation of Demographic and Socioeconomic Characteristics of All Households, 2009.

\begin{tabular}{|c|c|c|}
\hline & \multicolumn{2}{|c|}{ All Households } \\
\hline & Mean & SD \\
\hline \multicolumn{3}{|l|}{ Variables } \\
\hline Any Disability & 0.16 & 0.36 \\
\hline Ambulatory Disability & 0.09 & 0.29 \\
\hline \multicolumn{3}{|l|}{ Race/ethnicity } \\
\hline White & 0.69 & 0.46 \\
\hline Black & 0.13 & 0.34 \\
\hline Hispanic & 0.13 & 0.34 \\
\hline Asian & 0.05 & 0.21 \\
\hline \multicolumn{3}{|l|}{ Householder Vars } \\
\hline Native-Born & 0.15 & 0.36 \\
\hline Age (mean) & 49.08 & 16.94 \\
\hline Male & 0.54 & 0.50 \\
\hline Married household & 0.52 & 0.50 \\
\hline Kids under 18 & 0.35 & 0.48 \\
\hline \multicolumn{3}{|l|}{ Education } \\
\hline$<$ h.s. degree & 0.12 & 0.33 \\
\hline h.s. degree & 0.25 & 0.43 \\
\hline >h.s. degree & 0.63 & 0.48 \\
\hline \multicolumn{3}{|l|}{ Receipt of: } \\
\hline Public assistance & 0.02 & 0.13 \\
\hline Disability income & 0.07 & 0.26 \\
\hline Housing asst. & 0.04 & 0.19 \\
\hline Tot. hh inc (mean) & 70.68 & 71.53 \\
\hline Housing Tenure (owner) & 0.68 & 0.47 \\
\hline \multicolumn{3}{|l|}{ Time in unit/location } \\
\hline Duration in unit & 10.84 & 12.37 \\
\hline Located in suburb & 0.63 & 0.48 \\
\hline \multicolumn{3}{|l|}{ Region } \\
\hline Northeast & 0.20 & 0.40 \\
\hline South & 0.35 & 0.48 \\
\hline Midwest & 0.21 & 0.41 \\
\hline West & 0.24 & 0.42 \\
\hline $\mathbf{N}$ & \multicolumn{2}{|c|}{33,006} \\
\hline
\end{tabular}

\section{References}

Abedin, Shanti, Cathy Cloud, Alia Fierro, Debby Goldberg, Jorge Andres Soto, and Morgan Williams. 2018. Making Every Neighborhood a Place of Opportunity: A 2018 Fair Housing Trends Report. Washington: National Fair Housing Alliance (NFHA), Available online: http:/ / nationalfairhousing.org/wp-content/uploads / 2018/04/NFHA-2018-Fair-Housing-Trends-Report_4-30-18.pdf (accessed on 3 June 2018).

AHS (American Housing Survey). 2012. About the American Housing Surveys (AHS)-People and Households-U.S. Census Bureau. Available online: https://www.census.gov/housing/ahs/about/ (accessed on 8 November 2012).

Alba, Richard D., and John R. Logan. 1991. Variation on two themes: Racial and ethnic patterns in attainment of suburban residence. Demography 28: 431-53. [CrossRef]

Alba, Richard D., and John R. Logan. 1993. Minority Proximity to Whites in Suburbs: An Individual-Level Analysis of Segregation. American Journal of Sociology 98: 1388-427. [CrossRef]

Alba, Richard, and Víctor Nee. 2003. Remaking the American Mainstream: Assimilation and Contemporary Immigration. Cambridge: Harvard University Press. 
Allison, Paul. 1999. Comparing Logit and Probit Coefficients across Groups. Sociological Methods and Research 28: 186-208. [CrossRef]

AoA (Administration on Aging). 2011. U.S. Department of Health and Human Services-A Profile of Older Americans: 2011. Available online: http://www.aoa.gov/Aging_Statistics/Profile/2011/docs/2011profile. pdf (accessed on 24 March 2014).

Baum, Scott, Elizabeth Kendall, and Sanjoti Parekh. 2016. Self-assessed health status and neighborhood context. Journal of Prevention $\mathcal{E}$ Intervention in the Community 44: 283-95.

Brault, Mathew W. 2012. Americans with Disabilities: 2010-Household Economic Studies. Available online: http:/ /www.includevt.org/wp-content/uploads/2016/07/2010_Census_Disability_Data.pdf (accessed on 10 August 2012).

Burkhauser, Richard V., Barbara A. Butrica, and Michael J. Wasylenko. 1995. Mobility Pattern of Older Homeowners: Are Older Homeowners Trapped in Distressed Neighborhoods? Research on Aging 17: 363-84. [CrossRef]

Chan, Sewin, and Ingrid Ellen. 2016. Housing for an Aging Population. Housing Policy Debate 27: 167-92. [CrossRef]

Conley, D. 1999. Being Black, Living in the Red: Race, Wealth, and Social Policy in America. Berkeley: University of California Press.

Eggers, Frederick J., and Fouad Moumen. 2011. Disability Variables in the American Housing Survey. Washington, DC: U.S. Department of Housing and Urban Development Washington.

Ellen, Ingrid. G., Tod Mijanovich, and Dillman Keri-Nicole. 2001. Neighborhood Effects on Health: Exploring The Links and Assessing the Evidence. Journal of Urban Affairs 23: 391-408. [CrossRef]

Friedman, Samantha, and Emily Rosenbaum. 2007. Does Suburban Residence Mean Better Neighborhood Conditions for All Households? Assessing the Influence of Nativity Status and Race/Ethnicity. Social Science Research 36: 1-27. [CrossRef]

Froehlich-Grobe, Katherine, Gail Regan, Jacqueline Y. Reese-Smith, Katie M. Heinrich, and Rebecca E. Lee. 2008. Physical Access in Urban Public Housing Facilities. Disability and Health Journal 1: 25-29. [CrossRef] [PubMed]

Golant, Stephen M. 2008. Low-Income Elderly Homeowners in Very Old Dwellings: The Need for Public Policy Debate. Journal of Aging and Social Policy 2: 1-28. [CrossRef]

Hemingway, Laura. 2010. Taking a Risk? The Mortgage Industry and Perceptions of Disabled People. Disability E Society 25: 75-87.

Hemingway, Laura. 2011. Disabled People and Housing: Choices, Opportunities and Barriers. Bristol: Policy Press.

Hoffman, Denise W., and Gina A. Livermore. 2012. The House Next Door: A Comparison of Residences by Disability Status Using New Measures in the American Housing Survey. Cityscape 14: 5-33.

Iceland, John, and Melissa Scopilliti. 2008. Immigrant Residential Segregation in US Metropolitan Areas, 1990-2000. Demography 45: 79-94. [CrossRef] [PubMed]

Lee, Barrett A., Sean F. Reardon, Glenn Firebaugh, Chad R. Farrell, Stephen A. Matthews, and David O'Sullivan. 2008. Beyond the Census Tract: Patterns and Determinants of Racial Segregation at Multiple Geographic Scales. American Sociological Review 73: 766-91. [CrossRef] [PubMed]

Levy, Diane K., Claudia L. Aranda, Margery Austin Turner, Rob Pitingolo, Rob Santos, Helen Ho, and Doug Wissoker. 2015. Housing Discrimination in the Rental Housing Market against People Who are Deaf and People Who Use Wheelchairs: National Study Findings. Available online: http:/ / www.huduser. gov/portal/publications/fairhsg/hds_disability.html (accessed on 20 August 2018).

Logan, John R., and Richard D. Alba. 1993. Locational Returns to Human Capital: Minority Access to Suburban Community Resources. Demography 30: 243-68. [CrossRef] [PubMed]

Logan, John R., and Harvey Molotch. 1987. Urban Fortunes: The Political Economy of Place. Berkeley: University of California Press.

Massey, Douglas. S. 1985. Ethnic Residential Segregation: A Theoretical Synthesis and Empirical Review. Sociology and Social Research 69: 315-50.

Massey, Douglas S., and Nancy A. Denton. 1993. American Apartheid: Segregation and the Making of the Underclass. Cambridge: Harvard University Press.

Newman, Sandra. 2003. The Living Conditions of Elderly Americans. The Gerontologist 43: 99-109. [CrossRef] [PubMed] 
National Fair Housing Alliance (NFHA). 2013. Modernizing the Fair Housing Act for the 21st Century: 2013 Fair Housing Trends Report. Washington, DC: Available online: http:/ /www.nationalfairhousing.org/Portals / 33/2013_Fair_Housing_Trends_Report.PDF (accessed on 30 June 2013).

National Fair Housing Alliance (NFHA). 2014. Expanding Opportunity: Systematic Approaches to Fair Housing. Washington, DC: Available online: http:/ / nationalfairhousing.org/wp-content/uploads/2017/04/2014-0811_nfha_trends_report_2014.pdf (accessed on 10 June 2014).

Oliver, Melvin L., and Thomas Shapiro. 1995. Black Wealth/White Wealth. New York: Routledge.

Pynoos, Jon, and Christy M. Nishita. 2003. The Cost and Financing of Home Modifications in the United States. Journal of Disability Policy Studies 14: 68-73. [CrossRef]

Rosenbaum, Emily, and Samantha Friedman. 2001. Differences in the Locational Attainment of Immigrant and native-Born Households with Children in New York City. Demography 38: 337-48. [CrossRef] [PubMed]

Smith, Stanley K., Rayer Stefan, and Eleanor A. Smith. 2008. Aging and Disability: Implications for the Housing Industry and Housing Policy in the United States. Journal of American Planning Association 74: 289-306. [CrossRef]

Stanton, John F. 2002. Fair Housing Act and Insurance: An Update and the Question of Disability Discrimination. Hofstra Law Review 31: 141-206.

Turner, Margery A., Carla Herbig, Deborah Kaye, Julie Fenderson, and Diane Levy. 2005. Discrimination Against Persons With Disabilities: Barriers at Every Step. Washington, DC: Urban Institute.

U.S. Census Bureau. 2011. American Housing Survey for the United States: 2009. Current Housing Reports. Series H150/09. Washington: U.S. Government Printing Office.

White, Betty Jo, John Peaslee, and Joseph LaQuatra. 1994. Comparing Housing Affordability and Quality among Disability Households. Journal of Family and Economic Issues 15: 367-80. [CrossRef]

WHO. 2013. How to Use the ICF: A Practical Manual for Using the International Classification of Functioning, Disability and Health (ICF). Geneva: WHO. Available online: http://www.who.int/classifications/ drafticfpracticalmanual2.pdf?ua=1 (accessed on 20 August 2018).

(C) 2018 by the authors. Licensee MDPI, Basel, Switzerland. This article is an open access article distributed under the terms and conditions of the Creative Commons Attribution (CC BY) license (http:/ / creativecommons.org/licenses/by/4.0/). 